\title{
Further Ecological and Shoreline Stability \\ Reconnaissance Surveys of Back Island, Behm Canal, Southeast Alaska
}
J. S. Young
J. A. Strand
R. M. Ecker

September 1987

Prepared for

David Taylor Naval Ship R\&D Center under a Related Services Agreement with the U.S. Department of Energy under Contract DE-AC06-76RLO 1830

Pacific Northwest Laboratory Operated for the U.S. Department of Energy by Battelle Memorial Institute 


\section{DISCLAIMER}

This report was prepared as an account of work sponsored by an agency of the United States Government. Neither the United States Government nor any agency thereof, nor Battelle Memorial Institute, nor any of their employees, makes any warranty, expressed or implied, or assumes any legal liability or responsibility for the accuracy, completeness, or usefulness of any information, apparatus, product, or process disclosed, or represents that its use would not infringe privately owned rights. Reference herein to any specific commercial product, process, or service by trade name, trademark, manufacturer, or otherwise, does not necessarily constitute or imply its endorsement, recommendation, or favoring by the United States Government of any agency thereof, or Battelle Memorial Institute. The views and opinions of authors expressed herein do not necessarly state or reflect those of the United States Government or any agency thereof, or Battelle Memorial Institute.

\section{PACIFIC NORTHWEST LABORATORY operated by \\ BATTELLE MEMORIAL INSTITUTE for the \\ UNITED STATES DEPARTMENT OF ENERGY under Contract DE-AC06-76RLO 1830}

\begin{tabular}{|c|c|}
\hline \multicolumn{2}{|c|}{ Printed in the United States of America } \\
\hline \multirow{2}{*}{\multicolumn{2}{|c|}{$\begin{array}{l}\text { Available from } \\
\text { National Technical Information Service }\end{array}$}} \\
\hline & \\
\hline \multirow{3}{*}{\multicolumn{2}{|c|}{$\begin{array}{l}\text { United States Department of Commerce } \\
\qquad 5285 \text { Port Royal Road } \\
\text { Springfield, Virginia } 22161\end{array}$}} \\
\hline & \\
\hline & \\
\hline \multirow{2}{*}{\multicolumn{2}{|c|}{$\begin{array}{l}\text { NTIS Price Codes } \\
\text { Microfiche A01 }\end{array}$}} \\
\hline & \\
\hline \multicolumn{2}{|c|}{ Printed Copy } \\
\hline & Price \\
\hline Pages & Codes \\
\hline 001-025 & $\mathrm{A} 02$ \\
\hline 026-050 & $\mathrm{A} 03$ \\
\hline 051-075 & A04 \\
\hline $076-100$ & A05 \\
\hline $101-125$ & A06 \\
\hline $126-150$ & A07 \\
\hline 151-175 & $\mathrm{A} 08$ \\
\hline $176-200$ & $\mathrm{~A} 09$ \\
\hline 201-225 & A010 \\
\hline $226-250$ & A011 \\
\hline 251-275 & A012 \\
\hline $276-300$ & A013 \\
\hline
\end{tabular}


FURTHER ECOLOGICAL AND SHORELINE STABILITY RECONNAISSANCE SURVEYS OF BACK ISLAND, BEHM CANAL, SOUTHEAST ALASKA

J. S. Young

J. A. Strand

Battelle/Marine Research Laboratory Sequim, Washington

R. M. Ecker

Pacific Northwest Laboratory Richland, Washington

September 1987

Prepared for David Taylor Naval Ship R\&D Center under a Related Services Agreement with the U.S. Department of Energy Contract DE-ACO6-76RLO 1830 



\section{EXECUTIVE SUMMARY}

An initial diver reconnaissance at Back Island, Southeast Alaska, which surveyed proposed pier and cable crossing sites on the north and east sides of the island, was conducted May 20-22, 1986. A second diver reconnaissance of the intertidal and subtidal zones of Back Is land was performed June 7-12, 1987. The specific objective of this survey was to catalog potentially vulnerable shellfish, other invertebrates, and marine plant resources occurring at three proposed alternate pier sites on the west side of Back Island. Additionally, a limited survey of terrestrial vegetation was conducted in the vicinity of one of the proposed alternate pier sites. The specific objective of this survey was to describe the littoral (beach) community and to list the dominant plant species found there. Finally, a reconnaissance survey of the shoreline of Back Island was conducted to evaluate potential changes in shoreline stability resulting from construction of onshore portions of the Southeast Alaska Acoustic Measurement Facility (SEAFAC).

This effort was designed to supplement the existing environmental data base for Back Island that will be used during the National Environmental Policy Act (NEPA) documentation process. A NEPA document currently being prepared describes the site environment and assesses impacts from the proposed construction and operation of SEAFAC.

PHYSICAL DESCRIPTION OF INTERTIDAL AND SUBTIDAL ENVIRONMENTS

Back Island is about 190 acres in extent with about 120 acres of uplands and 70 acres of intertidal area. The shoreline of the island is about 2 miles long. A bedrock shelf composed of steeply dipping beds of slate and sandstone extends around the entire island. A narrow shingle beach is perched on the bedrock shelf. The shingle beach is from 10 to $20 \mathrm{~m}$ wide and extends from the normal high-tide line to the tree line at the extreme high-tide level. The upper portion of the shingle beach is composed of coarse slate/sandstone fragments devoid of vegetation, whereas the lower portion of the beach is composed of a finer grained material that supports intertidal vegetation. The nearshore subtidal area around Back Island is composed of conspicuous 
bedrock outcrops similar in nature to the intertidal bedrock shelf. Pockets in the bedrock are filled with cobbles and sand.

\section{INTERTIDAL AND SUBTIDAL ECOLOGY}

The marine ecosystem of the west shore of Back Island is typical of rocky shorelines of the protected North Pacific coast. Both intertidal and subtidal zones are generally dominated by algae. Brown (Fucus distichus) and red (Rhodomela larix) algae occur prominently in the high to mid-intertidal zone; green algae, including Blidingia minima, the Ulva/Monostroma complex, and an unidentified filamentous green, occupy the mid- to lower intertidal zone. The brown algal species Alaria marginata and Costaria costata are conspicuous at the seaward limit of the intertidal zone. Barnacles, periwinkles, hermit crabs, and limpets are closely associated with Fucus, while mussels and starfish are first encountered among the green algae.

Subtidally, either the brown alga Agarum sp. or the eelgrass Zostera marina predominates. Agarum is found on cobble and rock substrates, while Zostera is found on fine-grained substrates. The brown algae support a diverse fauna including rock jingles (rock oysters), serpulid worms, sponges, bryozoans, sea anemones, chitons, nudibranchs, gastropods, scallops, tunicates, and sea urchins. Eelgrass supports a different fauna composed of crabs, nudibranchs, limpets, sea urchins, sea cucumbers, and sea anemones. Finally, a zone generally devoid of vegetation is encountered seaward of the stands of Agarum or Zostera. Sea cucumbers, starfish, burrowing sea anemones, moon snails, and flatfish are characteristic fauna.

\section{TERRESTRIAL PLANT ECOLOGY}

The beach slopes gently from the tree line (extreme high water) to the mean high-water line, and the beach material overlying the bedrock is relatively thin. The distance from tree line to high-water line is generally less than $20 \mathrm{~m}$ in the vicinity of all three proposed alternate pier sites, but can be as wide as $60 \mathrm{~m}$ at other locations on the island.

The beach community is dominated by a mixed stand of sedges, rushes, grasses, and forbs. Sedge is common to the lower beach. The Arctic rush occurs in areas of closed drainage on the upper beach. At higher and drier 
elevations, both sedge and rush are replaced by beach rye, the aspect dominant in early June. Conspicuous forbs included buttercup, Pacific cinquefoil, sea coast angelica, yarrow, and few-flowered shooting star.

\section{SHORELINE STABILITY}

The shoreline of Back Island is fairly stable because an intertidal bedrock shelf that extends around the entire island protects it from most wave-induced erosion. Some erosion of uplands soils at the extreme high-tide line was evident during a reconnaissance survey on June 8,1987 . Placement of intertidal fill at the base of the proposed pier and construction of an access road along the shoreline between the pier and the proposed Range Operations Building could have some destabilizing effects on the shoreline of Back Island. The fill could cause increased wave-induced erosion of the upland soils in the immediate vicinity of the pier during extreme high tides and moderately strong winds. Clearing of trees and vegetation near the extreme high-tide line during construction of the access road and Range Operations Building could increase wave-induced erosion to upland soils; the root systems of the existing vegetation stabilize the soils by dissipating wave energy. Placement of fill in the intertidal zone could also hinder the free movement of logs and driftwood along the shoreline, resulting in damage to the pier. 



\section{ACKNOWLEDGMENTS}

This final report summarizes studies conducted June 6 , 1987, through July 15, 1987, by Pacific Northwest Laboratory (PNL) for the David Taylor Naval Ship R\&D Center (DTNSRDC), Puget Sound Detachment, Bremerton, Washington. This project was under the technical direction of Dr. John A. Strand, Battelle/Marine Research Laboratory, Sequim, Washington. Mr. James S. Young, also from the Battelle/Marine Research Laboratory, organized and conducted the diver surveys of Back Island. He was assisted by Mr. James A. Coley, Engineering and Craft Services Department, Battelle/Marine Research Laboratory. Ms. Laura Nightingale, a Northwest College and University Association for Science trainee, determined terrestrial plant taxonomy. Confirmatory plant identifications were made by Dr. Raymond Z. Riznyk, Alaska Pacific University, Anchorage, Alaska, and Mr. Edward L. Tisch, Peninsula College, Port Angeles, Washington. Mr. Richard M. Ecker, Geosciences Department, Pacific Northwest Laboratory, Richland, washington, performed the shoreline stability reconnaissance survey of Back Island.

Ms. Laurel Black of Anaglyph Art Services, Sequim, Washington, provided graphic art support. Editing was provided by Ms. Susan A. Kreml, Earth and Enviromental Sciences Center, Pacific Northwest Laboratory, Richland, Washington. 

CONTENTS

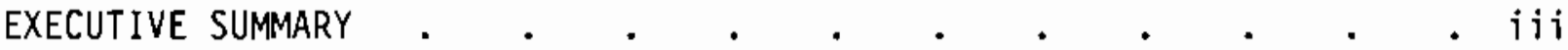

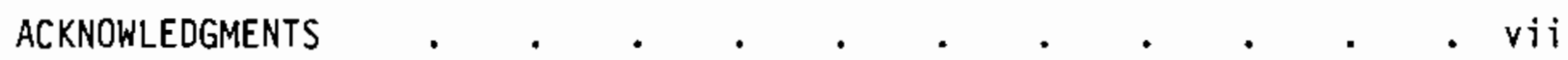
INTRODUCTION

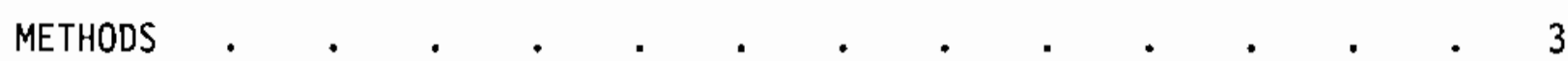

INTERTIDAL AND SUBTIDAL ECOLOGY $\quad . \quad . \quad . \quad . \quad . \quad . \quad$. 3

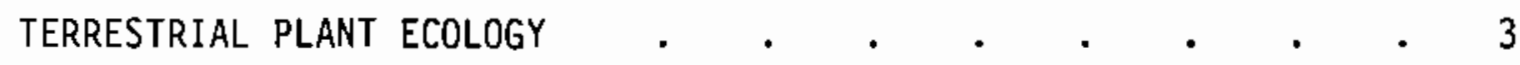

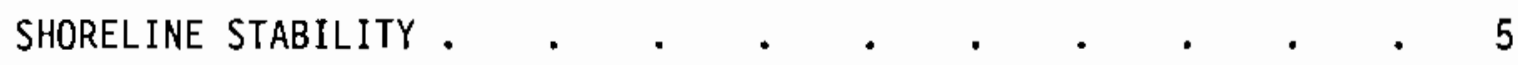

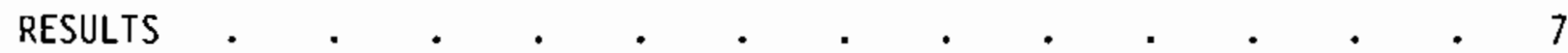

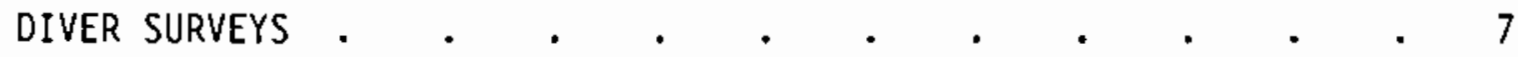

Transects 10-12 $\quad . \quad$. $\quad . \quad . \quad . \quad . \quad$. 8

Transects 13-15 . . . . . . . . . . . . . 9

Transects 16-18 . . . . . . . . . . . 9

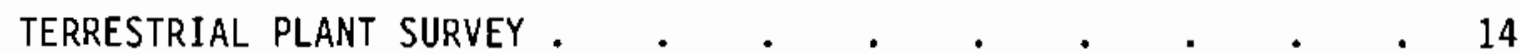

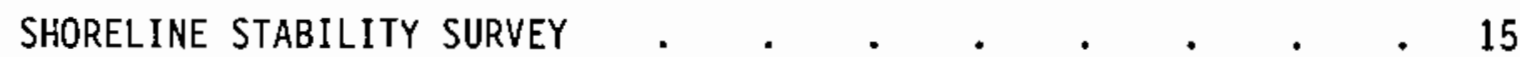

Description of Back Island Shoreline . . . . . 15

Shoreline Stability . $\quad$. . . . . . . . . 16

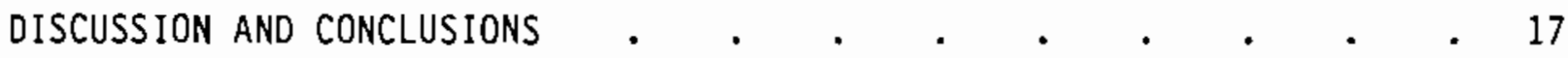

PHYSICAL DESCRIPTION OF INTERTIDAL AND SUBTIDAL ENVIRONMENTS $\quad 17$

INTERTIDAL AND SUBTIDAL ECOLOGY $\quad \cdot \quad \cdot \quad \cdot \quad \cdot \quad \cdot \quad \cdot \quad$ • 17

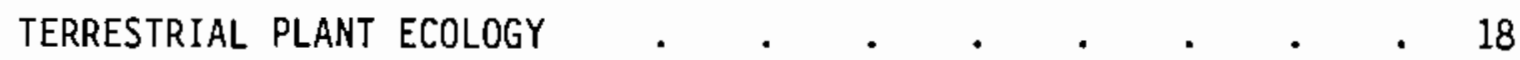

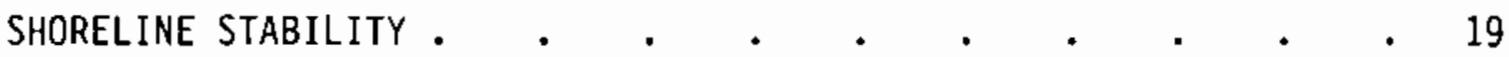

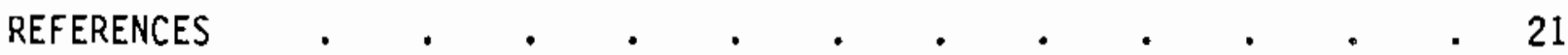

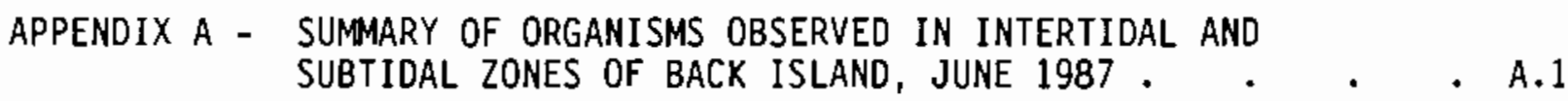

APPENDIX B - SUMMARY OF DOMINANT TERRESTRIAL PLANTS OBSERVED IN VICINITY OF TRANSECT 6 FROM HIGH-WATER LINE TO

TREE LINE • • • • • • • • • • • 


\section{FIGURES}

1 Locations of Diver Transects at Back [s] and, Southeast

Alaska . . . . . . . . . . . . 4

2 Benthic Profiles for Transects 10-12 Show Substrate Type and

Predominant Flora and Fauna . . . . . . . . 10

3 Benthic Profiles for Transects 13-15 Show Substrate Type and

Predominant Flora and Fauna . . . . . . . . . 12

4 Benthic Profiles for Transects 16-18 Show Substrate Type and

Predominant Flora and Fauna . . . . . . . . . 13

\section{TABLES}

1 Key to Symbols for Substrate Types, Flora, and Fauna Used in

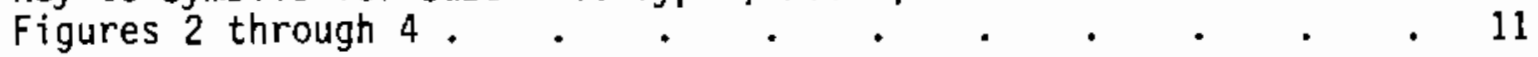

A.1 Summary of Organisms Observed in Intertidal and Subtidal Zones

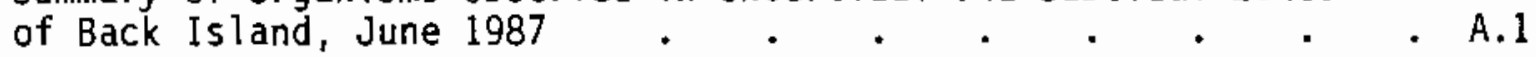

B.1 Summary of Dominant Terrestrial Plants Observed in Vicinity of Transect 6 from High-Water Line to Tree Line. . . . . B.1 


\section{$\underline{\text { INTRODUCTION }}$}

In the course of the National Environmental Policy Act (NEPA) documentation process for the proposed Behm Canal Southeast Alaska Acoustic Measurement Facility (SEAFAC), David Taylor Naval Ship R\&D Center (DTNSRDC) contracted Pacific Northwest Laboratory (PNL) to conduct environmental surveys and other studies to improve the data base used in preparing the site description and requisite assessment of impacts. In a previous study conducted for OTNSRDC based on a literature review and interviews of relevant professional resources (Strand et al. 1986), PNL found that available data were insufficient to meet certain NEPA requirements, particularly in the areas of aquatic and terrestrial ecology.

This report presents the results of a second diver reconnaissance of Back Is land conducted June 7-12, 1987. Substrate types, vegetative zones, and dominant invertebrate communities encountered at three alternate pier sites are described. As in the first diver reconnaissance (Strand and Young 1986), these results are qualitative, and no attempt was made to rigorously quantify the distribution and diversity of indigenous organisms.

Additionally, this report presents findings of limited surveys of terrestrial vegetation and shoreline stability in the vicinity of the alternate pier sites. These data are also qualitative because the objective of the survey was to describe the shoreline environment and the beach community, and to list the dominant plant species encountered. 



\section{METHODS}

INTERTIDAL AND SUBTIDAL ECOLOGY

Transect lines were established at key locations on the west side of Back Island (Figure 1) and extended due west from the high-water line for either 100 or $150 \mathrm{~m}$, depending on the extent of the subtidal vegetation. Using SCUBA, observations of substrate composition and of plant and animal communities were made at intervals at a maximum of $10 \mathrm{~m}$ along the line. Any significant observations between the intervals, such as changes in vegetation or substrate type, were also noted. Depth in feet was recorded at each interval.

Nine transects were divided into three sets of three each. Each set was in the vicinity of one of three possible construction sites for the pier; the center transect was placed at a proposed pier site and the other transects at either side of the proposed site. The 1987 transect numbers are a continuation of those (1-9) used in the 1986 surveys (Strand and Young 1986).

Where possible, identifications of indigenous plants and animals were made in the field. A few plant specimens were dried and pressed for additional study. Also, a few animal species were preserved in $10 \%$ buffered formalin for later laboratory examination. The general taxonomic keys of Abbott and Hollenberg (1976) and Kozloff (1976) were used together with supplementary publications to identify specific taxonomic groups (Waaland 1977; Guberlet 1956; Kozloff 1973; Johnson and Snook 1927; Scagel 1966, 1971; Ricketts and Calvin 1939; Kessler 1985; Barr and Barr 1983).

\section{TERRESTRIAL PLANT ECOLOGY}

Dominant vascular plants were sampled in the vicinity of Transect 6 from the tree line to the high-water line. The entire plant inclusive of roots, stems, leaves, flowers, and/or seeds was collected and placed in zip-lock plastic bags for transport to the laboratory. The taxonomic keys of Mason (1957), Hulten (1968), and Hitchcock and Cronquist (1974) were used in plant identification. 


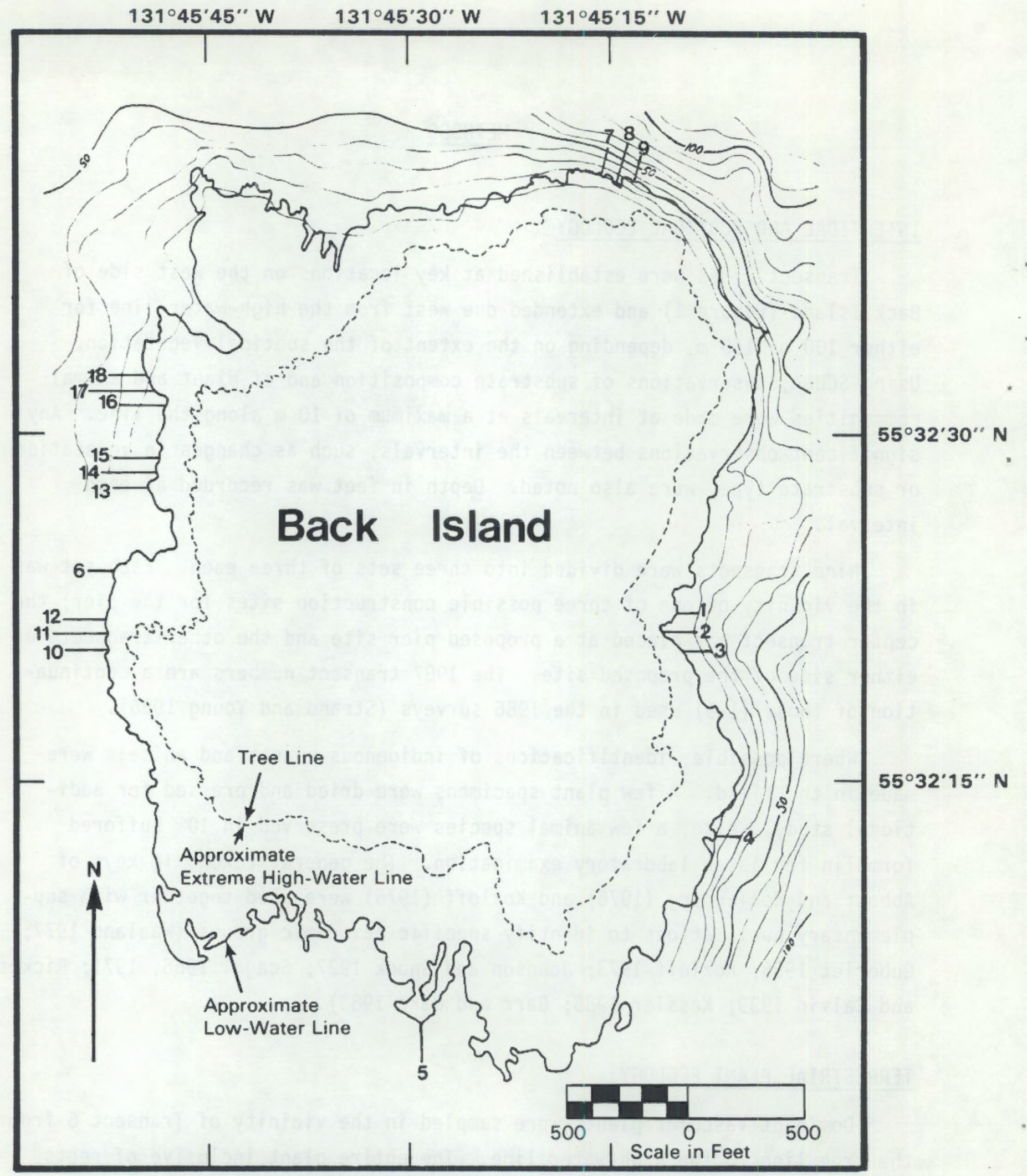

FIGURE 1. Locations of Diver Transects (numbered) at Back Island, Southeast Alaska 


\section{SHORELINE STABILITY}

A reconnaissance survey of the shoreline of Back Island was performed on June 8,1987 , to assess potential effects on shoreline stability from construction of the onshore portions of SEAFAC. The SEAFAC project will require construction of a pier and an access road from the pier to the Range Operations Building. Some intertidal fill may be used to provide a foundation for the pier where it attaches to the shore. The access road will be parallel to the extreme high-water shoreline. A visual inspection of the original pier site, three alternate pier sites, and the Range Operations Building site was made during the survey. 



\section{$\underline{\text { RESULTS }}$}

\section{DIVER SURVEYS}

Several intertidal and subtidal zones were common to all transects on the west side of the island. The high intertidal zone began at the high-water line where grasses and other vascular plants were replaced by the brown alga Fucus distichus, which grew directly on bedrock. Fucus was stunted in the highest reaches of the zone, but became fully developed within 10 or $15 \mathrm{~m}$ below the zone's upper edge. Fucus was soon joined by the red alga Rhodomela larix. Barnacles (Balanus sp.), periwinkles (Littorina sitkana), hermit crabs (Pagurus spp.), and limpets (Notoacmea scutum) were the dominant fauna. We called this assemblage the Fucus/Rhodomela zone.

Rhodomela was soon replaced by a mixed stand of green algae that included Blidingia minima, the Ulva/Monostroma complex, and an unidentified filamentous green that resembles Rhizoclonium sp. Because Fucus was still present in this mid- to low intertidal zone, we called it the Fucus/mixed green algal zone. It included a band of mussels (Mytilus edulis) and occasional starfish (Pisaster ochraceus and Dermasterias imbricata) in addition to the fauna that were found in the Fucus/Rhodomela zone. In the lower half of this intermediate zone, the red alga Halosaccion glandiforme was sometimes observed, and at the seaward edge there was a narrow band of the brown alga Alaria marginata with occasional Costaria costata, another brown algal species. Substrate for the Fucus/mixed green algal zone consisted mostly of bedrock, with hollows between the rocky outcrops that were often filled with cobble. Except for their widths, these two zones were very similar at all transects visited. The Fucus/mixed green algal zone ended abruptly at a rock ledge that ranged from 0.5 to $2.5 \mathrm{~m}$ high depending on transect position.

The next deeper zone, primarily subtidal, was dominated by patchy beds of the brown alga Agarum sp., if the substrate was rocky, or eelgrass (Zostera marina) if the substrate was sandy. Agarum was associated with coralline red algae, and the dominant fauna were rock jingles (Pododesmus cepio) and serpulid worms (Serpula vermicularis). Other invertebrates observed in the Agarum beds included the sponge Myxilla incrustans, bryozoans (Heteropora sp.), the anemone Tealia lofotensis, chitons (Tonicella lineata, Cryptochiton stelleri), 
nudibranchs (Berthella californica, Melibe leonina), gastropods (Fusitriton oregonensis, Ceratostoma foliatum, Searlesia dira), scallops (Hinnites multirugosus, Chlamys hastata hericia), shrimp (Pandalus danae), tunicates (Cnemidocarpa finmarkiensis, Halocynthia aurantium), and sea urchins (Strongylocentrotus franciscanus, $\underline{s}$. droebachiensis). The echinoderms Pycnopodia helianthoides and Parastichopus californicus were also common to both Agarum and Zostera beds.

The last zone encountered was completely subtidal and located on a sand substrate. It was largely devoid of vegetation except for a few red algae and infrequent blades of Agarum sp. The sea cucumber Parastichopus, the starfish Pycnopodia, and the burrowing anemone Pachycerianthus fimbriatus were characteristic fauna. Eggs of the moon snail Lunatia lewisif were common, as were flatfish such as rock sole, Lepidopsetta bilineata. This we called the sparsely vegetated zone.

The intertidal and subtidal zones sloped gradually and generally little or no tidal current prevailed. Wave action was also negligible unless winds intensified, particularly when from the west.

Transects $10-12$

Transects 10, 11, and 12 (Figure 2), each $100 \mathrm{~m}$ in length, were located at the southernmost of the alternate pier sites. The two intertidal zones, Fucus/Rhodomela and Fucus/mixed green algae, covered the first 42, 31, and $45 \mathrm{~m}$ of Transects 10,11 , and 12, respectively. A dense bed of Agarum was seen along Transect 10 between 42 and $66 \mathrm{~m}$; however, Zostera could be seen about $6 \mathrm{~m}$ to the south. Zostera was also found between 66 and $77 \mathrm{~m}$, along with the crabs Pugettia gracilis and Telmessus cheiragonus and the sea urchin strongylocentrotus droebachiensis. The sparsely vegetated zone extended beyond $77 \mathrm{~m}$ from the beginning of the transect.

Alternating patches of Agarum and eelgrass occurred between 31 and $67 \mathrm{~m}$ along Transect 11. A sparsely vegetated zone was encountered between 67 and $94 \mathrm{~m}$. The transect ended on a rock outcrop covered by Agarum. The chitons, Cryptochiton stelleri and Tonicella lineata, and the rock scallop, Hinnites multirugosus, were also found in the Agarum beds. 
In. Transect 12, a narrow band of Agarum was observed between 45 and $51 \mathrm{~m}$ and a wide bed of eelgrass between 51 and $79 \mathrm{~m}$. This transect also ended on a small Agarum-covered rocky outcrop.

Other plants and animals encountered on this set of transects are shown in Appendix A; symbols on Figures 2, 3, and 4 appear in Table 1 (p. 11). Transects $13-15$

Transects 13, 14, and 15, each $150 \mathrm{~m}$ in length, were located at the favored alternate pier site. The two intertidal zones were considerably wider than in the previous set of transects, extending 80,74 , and $73 \mathrm{~m}$, respectively, from the high-water mark. Along Transect 13, a dense Agarum bed covered the area between 80 and $127 \mathrm{~m}$, while Zostera formed a zone only $2 \mathrm{~m}$ wide between 127 and $129 \mathrm{~m}$. The sparsely vegetated zone extended out to a group of small, Agarum-covered rock outcrops near the end of the transect.

On Transect 14, eelgrass was limited to a few scattered plants growing at $77 \mathrm{~m}$. Agarum dominated from $74 \mathrm{~m}$ to the end of the transect, except in a few sandy spots along the last $30 \mathrm{~m}$. A dense eelgrass bed, however, occurred $10 \mathrm{~m}$ north of the transect line.

Agarum was encountered at $73 \mathrm{~m}$ along Transect 15 but the vegetation changed to eelgrass at $80 \mathrm{~m}$ when the substrate changed from rock to sand. The sand and eelgrass extended to $96 \mathrm{~m}$, where again the substrate became rocky and Agarum was dominant. The sparsely vegetated zone began at $120 \mathrm{~m}$ when the bottom again became sandy. A few eelgrass plants were observed out to $150 \mathrm{~m}$ from mean high water.

Specific fauna observed are listed in Appendix A (Table A.1).

\section{Transects $16-18$}

Transects 16,17 , and 18 (Figure 4), also $150 \mathrm{~m}$ in length, were located at the northernmost alternate pier site. Their intertidal vegetation zones ran a total length of 82,68 , and $58 \mathrm{~m}$, respectively. Bedrock extended out to $117 \mathrm{~m}$ on Transect 16, supporting a dense bed of Agarum from $82 \mathrm{~m}$ to the bedrock-sand transition. Beyond $117 \mathrm{~m}$, a typical sparsely vegetated sandy bottom was present; here Pycnopodia and Parastichopus were common. 
Transect 10

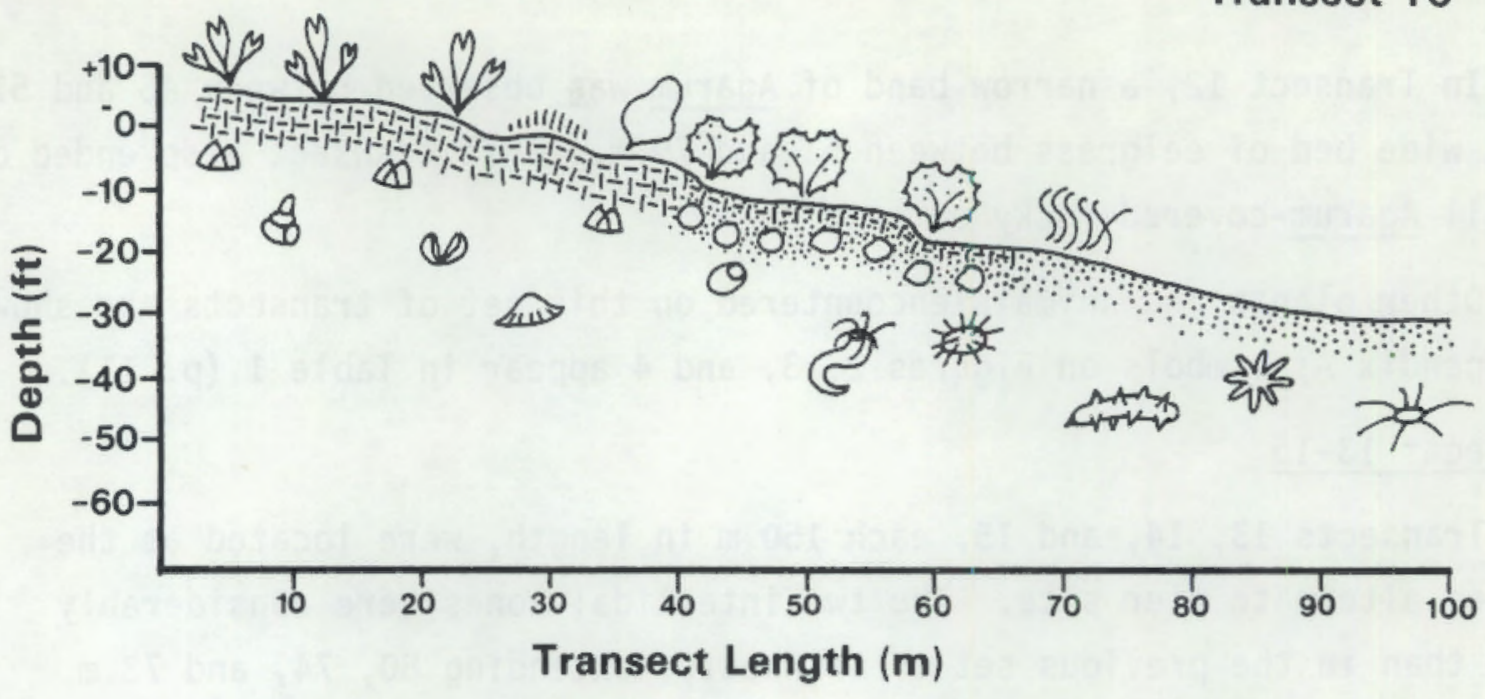

Transect 11

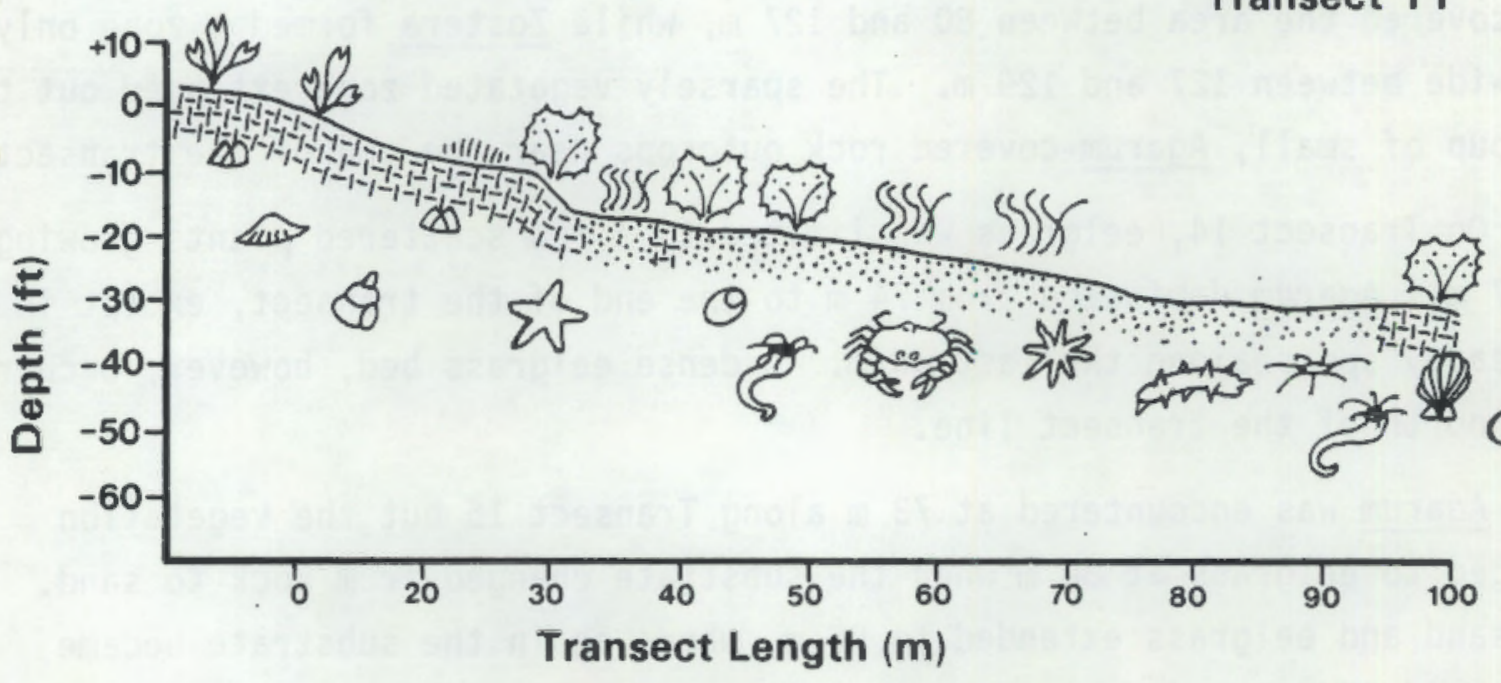

Transect 12

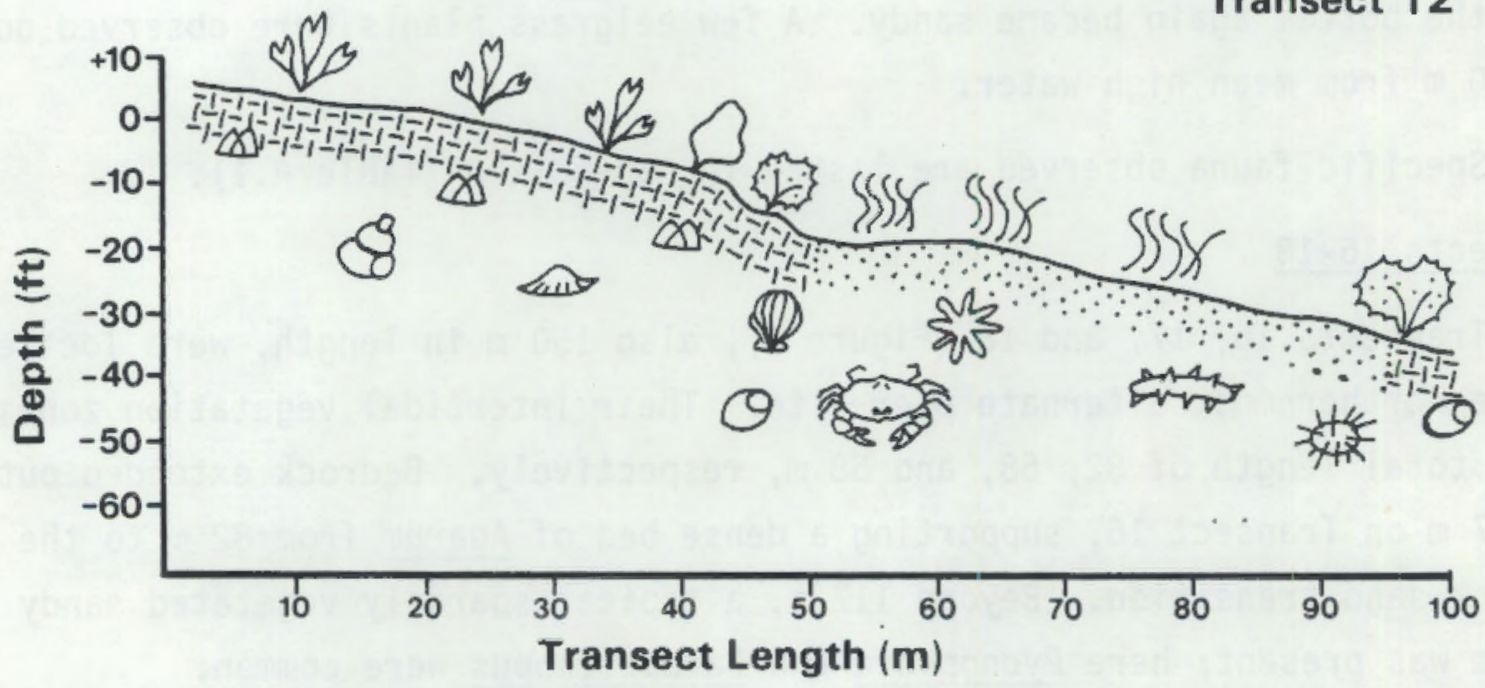

FIGURE 2. Benthic Profiles for Transects 10-12 Show Substrate Type and Predominant Flora and Fauna. A key to symbols used is found in Table 1. 
TABLE 1. Key to Symbols for Substrate Types, Flora, and Fauna Used in Figures 2 through 4

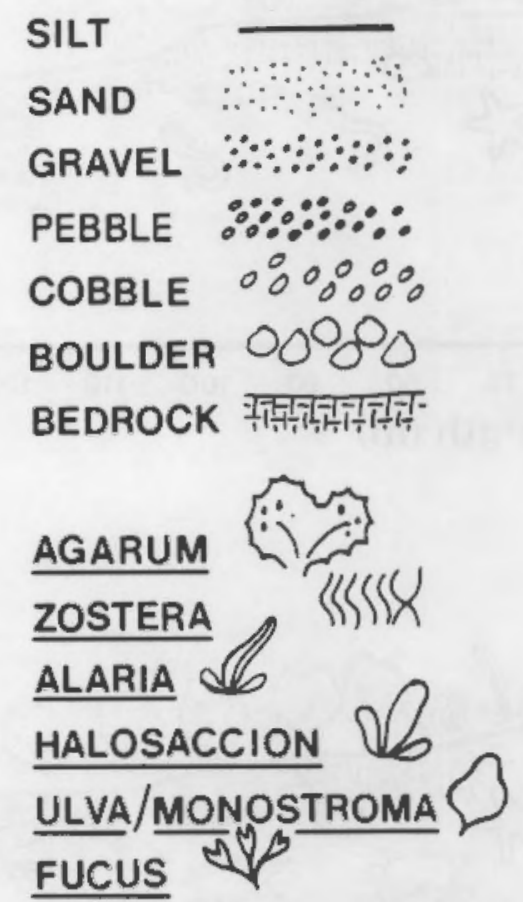

FILAMENTOUS GREEN ALGAE "wllum

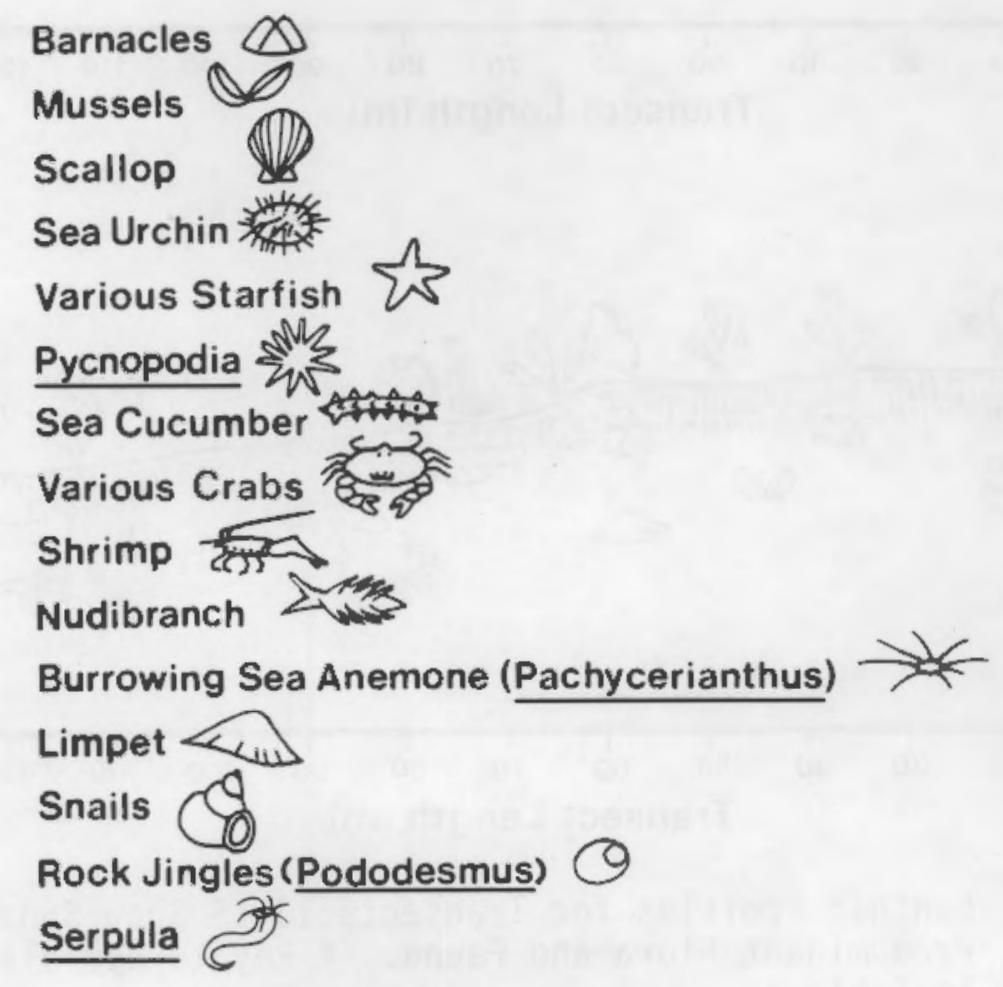


Transect 13

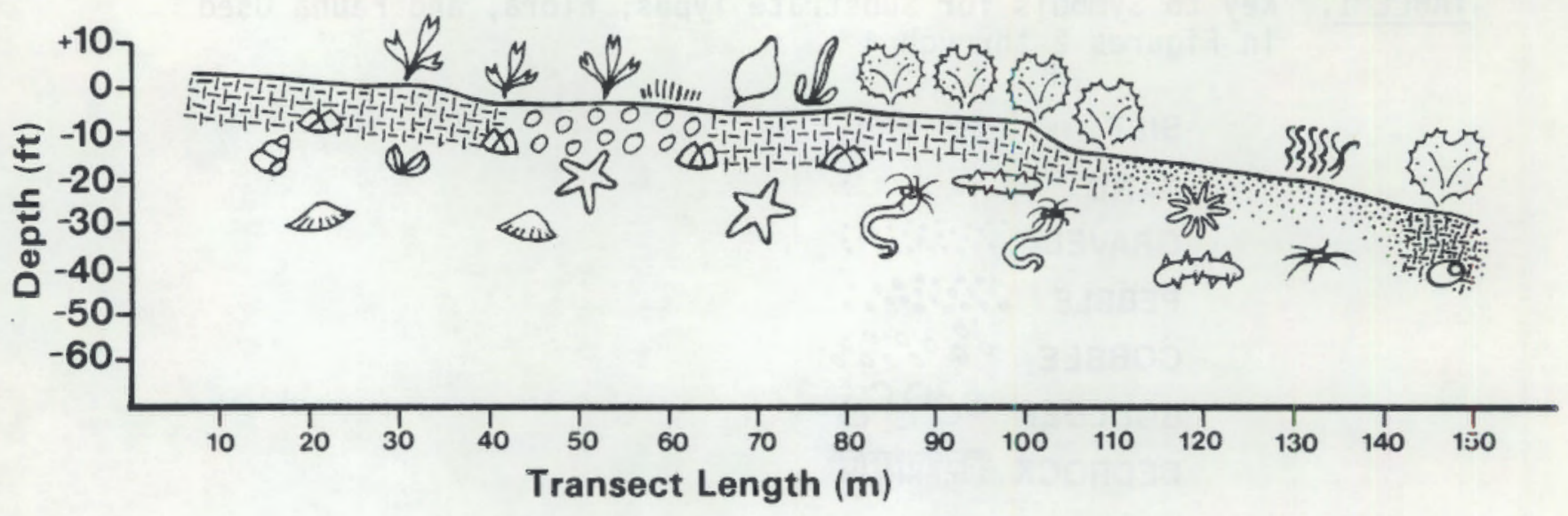

Transect 14

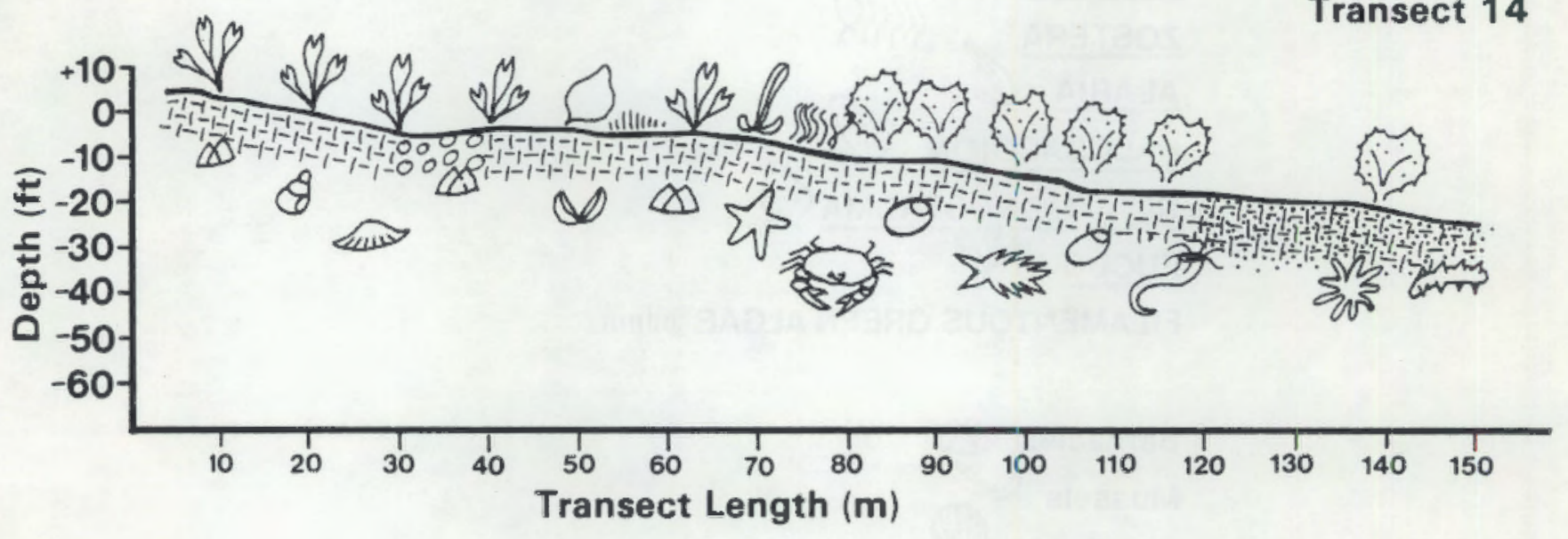

Transect 15

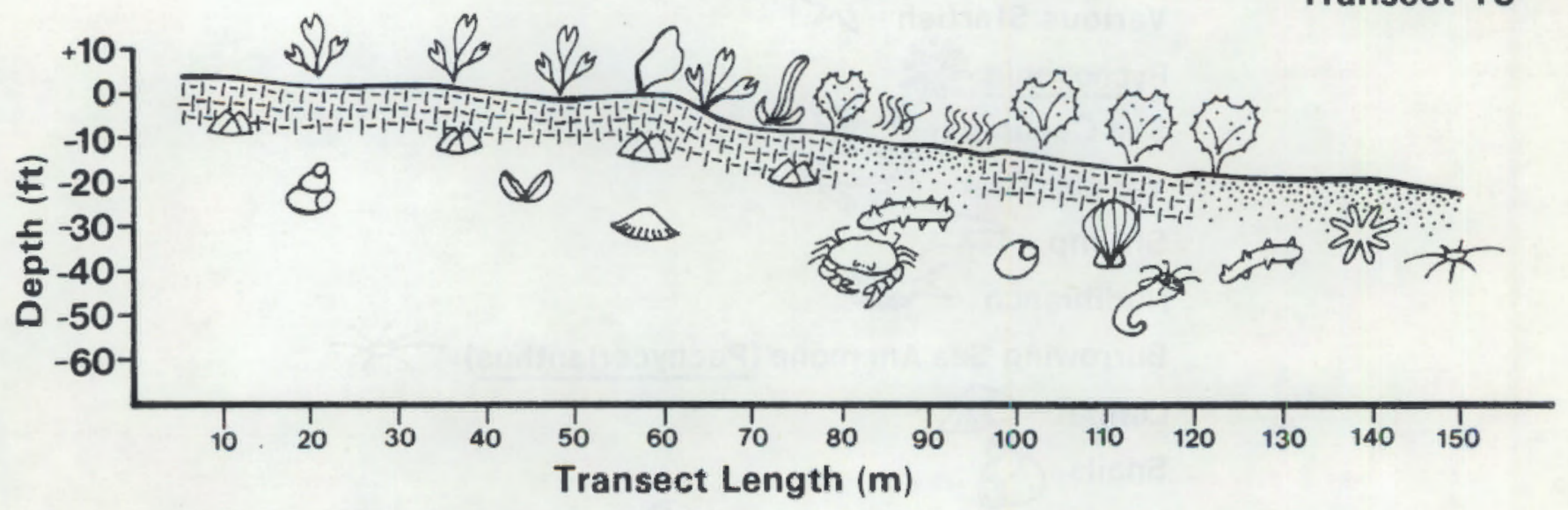

FIGURE 3. Benthic Profiles for Transects 13-15 Show Substrate Type and Predominant Flora and Fauna. A key to symbols used is found in Table 1. 
Transect 16

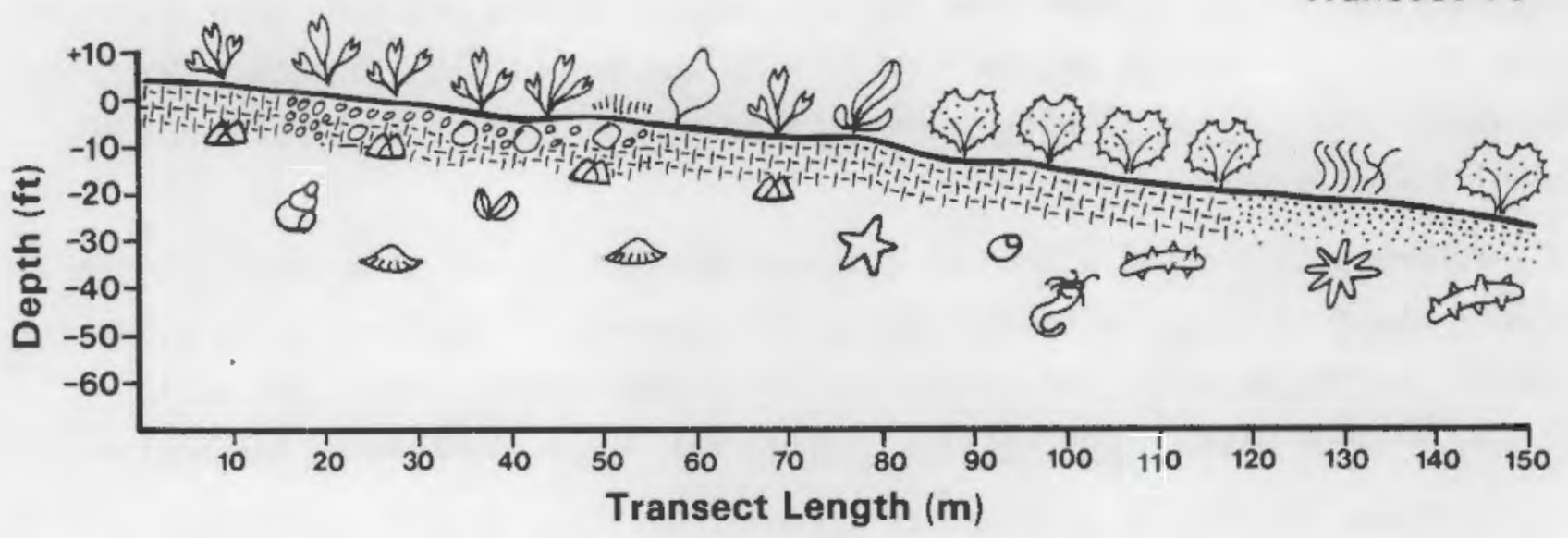

Transect 17

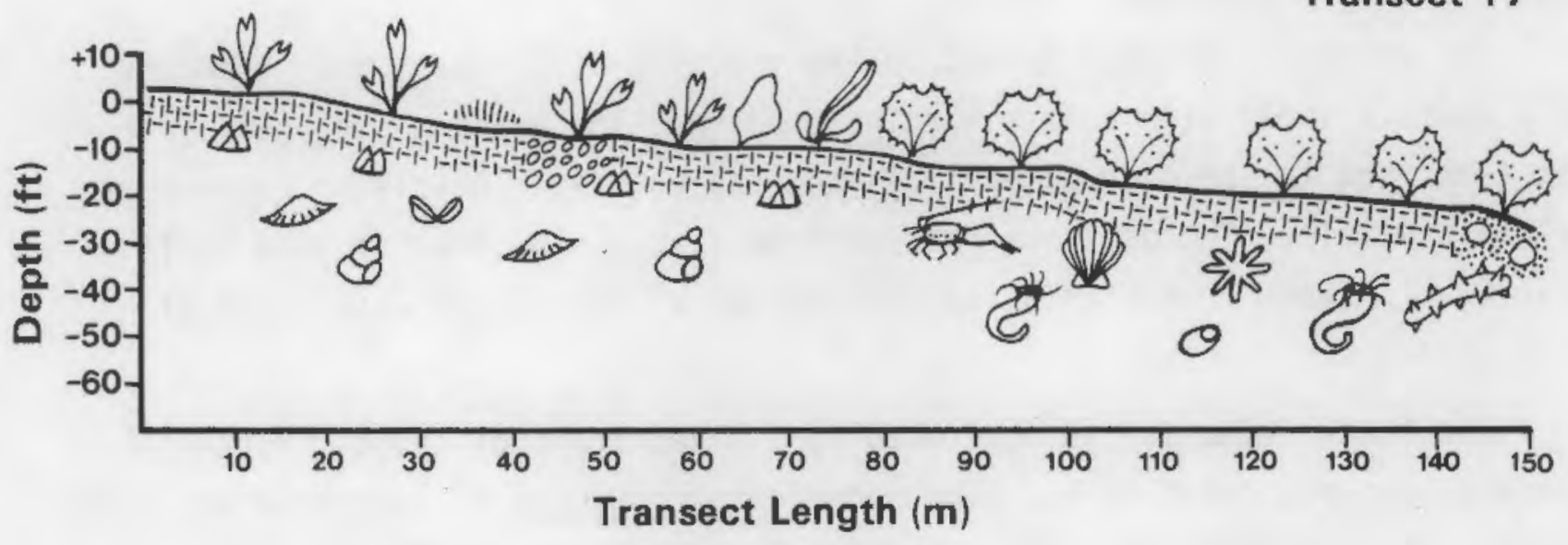

Transect 18

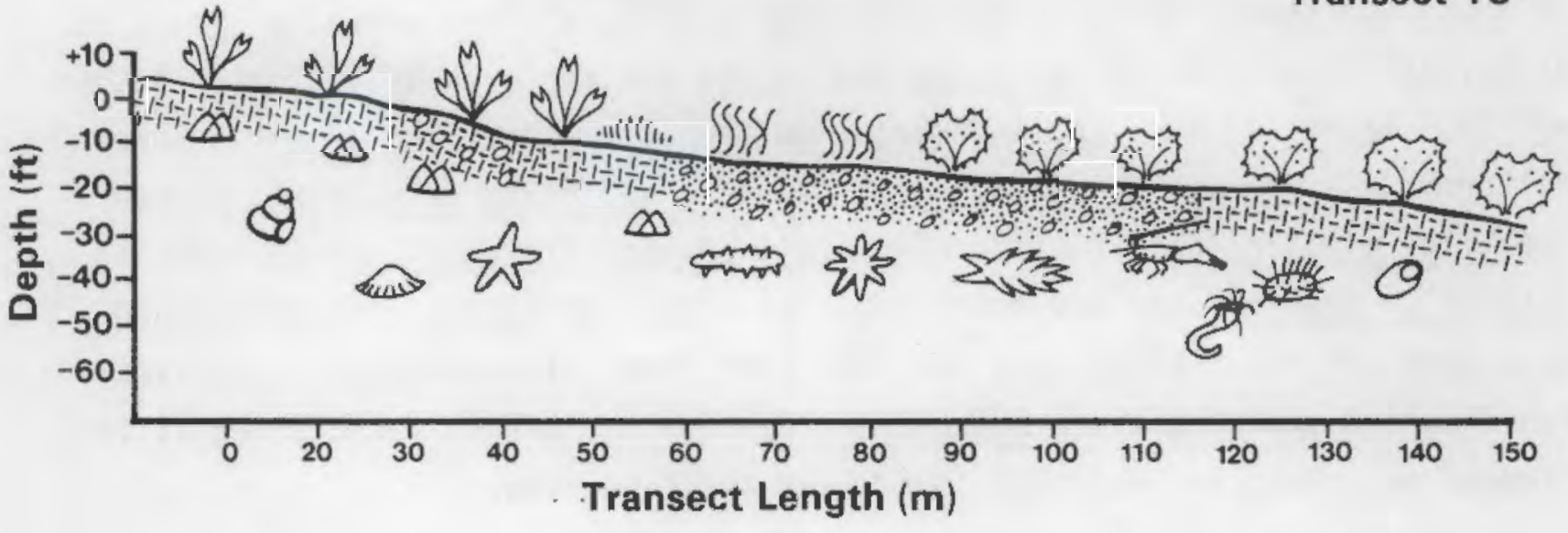

FIGURE 4. Benthic Profiles for Transects 16-18 Show Substrate Type and Predominant Flora and Fauna. A key to symbols used is found in Table 1. 
Transects 17 and 18 never reached a sparsely vegetated zone. Bedrock continued out to $143 \mathrm{~m}$ along Transect 17, where boulders and sand were observed. Dense Agarum covered the bottom from $68 \mathrm{~m}$ to the end of the transect. The red alga, Constantinea simplex, grew in some of the small spaces between individual Agarum plants.

Transect 18 crossed a band of eelgrass between 58 and $77 \mathrm{~m}$, beyond which a dense stand of Agarum extended out to the 150-m end. The band of eelgrass, however, curved westward and paralleled the transect line $8 \mathrm{~m}$ to the north out to the 94-m mark. Constantinea simplex was again found among the Agarum.

A faunal listing is provided in Appendix A (Table A.1).

\section{TERRESTRIAL PLANT SURVEY}

The shoreline of Back Island in the vicinity of Transect 6 is composed of a bedrock shelf with a narrow shingle beach. The beach slopes gently from the tree line to the high-water line, and the materials overlying bedrock are relatively thin. The distance between tree line and high-water line is less than $20 \mathrm{~m}$. These characteristics are typical of the entire west shore of Back Island.

The beach community is dominated by a mixed stand of sedges, rushes, grasses, and scattered forbs. The sedge Carex lyngbyei is common on the lower beach. It is replaced by the rush Juncus articus (perhaps Juncus balticus) in areas of closed drainage. Sea plantain (Plantago maritima) is also common to the lower beach in niches on rocks that are above the high-water line. At higher and drier elevations, Carex and Juncus are replaced by wild rye, Elymus mollis. Elymus is the aspect dominant on the upper shoreline in early June. 8uttercup (Ranunculus orthoryhnchus), plantain (Plantago canescens), yarrow (Achillea millifolium), Pacific cinquefoil (Potentilla pacifica) (perhaps Potentilla egedii), and sea coast angelica (Angelica lucida) are also found at higher and drier elevations near the tree line. The conspicuous but small few-flowered shooting star, Dodecatheon pulchellum, was in full flower at the time of our visit and was also found near the tree line. 


\section{SHORELINE STABILITY SURVEY}

\section{Description of Back Island Shoreline}

Back Island is located on the east shore of western Behm Canal about $1 \mathrm{mile}$ west of Revillagigedo Island, less than $1 / 2$ mile northeast of Betton Is I and, and less than $1 / 2$ mile southwest of Grant Island. Back Island is about $700 \mathrm{~m}$ wide east to west by $975 \mathrm{~m}$ north to south and includes about 120 acres of uplands densely vegetated with forest and shrub-type vegetation. The high-water shoreline of Back Island is about $2 \mathrm{miles}$ long. The intertidal zone (between high and low tide) includes about 70 acres of bedrock shelf, tide pools, and a narrow band of vegetation and shingle/shale beach perched on the bedrock shelf. The shingle/shale beach is strewn with logs and driftwood, with some freshwater pools and channels just below the highwater shoreline.

The intertidal bedrock shelf that extends around the island is composed of thin beds of Upper Triassic slate and interbeds of sandstone. These thin beds dip steeply and strike to the northwest-southeast. The bedrock shelf extends from below the low-water line to about the high-tide line. The bedrock is fairly durable and protects the perched shingle/shale beach and vegetation from wave erosion during normal high tides. The presence of logs and driftwood on the upper part of the shingle/shale beach and minor soil erosion and the exposure of tree and undergrowth root systems at the extreme high-tide line indicate that the bedrock shelf may not effectively protect the upper shore from erosion during high tides and moderately strong winds.

The width of the shingle/shale beach varies from 10 to $20 \mathrm{~m}$. The upper portion of the beach consists of clean slate/sandstone fragments from 0.5 to 3 in. in diameter that apparently originated from the exposed bedrock of the island. The lower portion of the beach is composed of a finer grained material with slate fragments interspersed. This material is saturated with fresh water and is sparsely to moderately vegetated with grasses and intertidal vegetation. Small freshwater pools and interconnecting channels are present throughout much of the lower portion of the perched beach. 


\section{Shoreline Stability}

The shoreline of Back Island is fairly stable because of the low bedrock shelf surrounding the island. The shingle/shale beach is protected from wave action by the low bedrock shelf except during extreme high tides and moderately strong winds. The presence of beach grasses just above the normal high-tide line and of intertidal vegetation below the high-tide line also indicates that the shoreline is stable. Moderate erosion of uplands soils at the tree line around the island has left a low scarp at the seaward extent of the soils and exposed the dense root systems of trees and undergrowth. Erosion at the extreme high-tide line indicates that waves do reach the tree line during high tides and moderately strong winds and have caused some erosion to the soils. The dense root systems of trees and undergrowth exposed at the extreme high tide line appear to be fairly effective at providing protection of the soils from wave-induced erosion. 


\section{DISCUSSION AND CONCLUSIONS}

PHYSICAL DESCRIPTION OF INTERTIDAL AND SUBTIDAL ENVIRONMENTS

Back Island is about 190 acres in extent with about 120 acres of uplands and 70 acres of intertidal area. The shoreline of the island is about 2 miles

long. A bedrock shelf composed of steeply dipping beds of slate and sandstone extends around the entire island. A narrow shingle beach is perched on the bedrock shelf. The shingle beach is from 10 to $20 \mathrm{~m}$ wide and extends from the normal high-tide line to the tree line at the extreme high-tide level. The upper portion of the shingle beach is composed of coarse slate/sandstone fragments devoid of vegetation, whereas the lower portion of the beach is composed of a finer grained material that supports intertidal vegetation. The nearshore subtidal area around Back Island is composed of conspicuous bedrock outcrops similar in nature to the intertidal bedrock shelf. Pockets in the bedrock are filled with cobbles and sand.

\section{INTERTIDAL AND SUBTIDAL ECOLOGY}

As established in earlier diver surveys (Strand and Young 1986), the marine ecosystem of the western shore of Back Island is typical of rocky shorelines of the protected North Pacific coast (Ricketts and Caivin 1939; Kozloff 1973).

Intertidal communities were generally dominated by algae. Brown (Fucus distichus) and red (Rhodomela larix) algae were prominent in the high to midintertidal (supralittoral) zone. Barnacles, periwinkles, hermit crabs, and limpets were faunal types most often encountered. Green algae, including Blidingia minima, the Ulva/Monostroma complex, and an unidentified filamentous green (possibly Rhizoclonium sp.), were indicative of the mid- to lower intertidal (midlittoral) zone. These algae supported a fauna that included mussels, starfish, and some of the same species found in the upper intertidal zone. At the lowest levels of the intertidal (midlittoral-sublittoral) zone, the red alga halosaccion glandiforme was sometimes observed. The brown algae Alaria marginata and Costaria costata were conspicuous in a narrow band at the seaward limit of the zone. 
The subtidal communities of the western approach to Back Island were also dominated by both algae and higher plant species. Here also, in general terms, the brown alga Agarum sp. was found on cobble and rocky substrates while eelgrass (Zostera marina) occurred on sandy substrates. The dominant fauna associated with Agarum sp. included rock jingles, serpulid worms, sponges, bryozoans, sea anemones, chitons, nudibranchs, gastropods, scallops, tunicates, and sea urchins. A different fauna was supported by the eelgrass and included crabs, nudibranchs, limpets, gastropods, sea urchins, sea cucumbers, and sea anemones. Finally, a zone generally devoid of vegetation was encountered seaward to the stands of Agarum and Zostera. Sea cucumbers, starfish, burrowing sea anemones, moon snails, and flatfish were characteristic fauna.

The species compositions encountered during the present diver surveys, both plant and animal, are similar to those recorded earlier by Strand and Young (1986) at Back Island and by the U.S. Department of Interior and the U.S. Department of Commerce (1985) at log rafting and transfer sites on nearby Dall Island, Jumbo Island, and Prince of Wales Island. They are also nearly the same as found by VTN $(1980,1981,1982 a, b)$ at Boca de Quadra, Wilson Arm, and Sneaton Bay (about 80 miles southeast of Ketchikan), the site of the proposed Quartz Hill molybdenum mine. Finally, there are many similarities to the flora and fauna list assembled for Amchitka Island (Lebednick and Palmisano 1977; O'Clair 1977).

Variations in the composition and position of intertidal zones between the present and past studies are believed attributable to local environmental factors including slope, exposure, freshwater runoff, and nutrient enrichment to the more protected areas of shoreline. Any variations of composition and zonation of subtidal plants and animals are likely attributable to differences in substrate type and slope, currents, deposition of sediments, and season. Unfortunately, few other data are available for Back Island and Behm Canal (Strand et al. 1986) on which to base additional comparisons.

\section{IERRESTRIAL PLANT ECOLOGY}

The dominant littoral (beach) species found during the present survey are similar to those recorded at the heads of Wilson Arm, Boca de Quadra, and Bakewell Arm (VTN 1982c; Meehan and Bramlet 1983). At these locations, low 
estuarine marshes (below mean high-water level) are dominated by Lyngbye sedge, hairgrass, and Canadian bluejoint, while the high estuarine marshes (above mean high-water level) are dominated by Canadian bluejoint, hairgrass, Pacific reedgrass, beach rye, and awn sedge. Important forbs include cow parsnip, beach lovage, sea coast angelica, great red paintbrush, wild iris, and yarrow. Beneath these plants, a dense ground cover of bedstraw, pearlwort, sand spurry, and goose-tongue is present.

None of the plants in Southeast Alaska is either proposed for listing or is currently listed as threatened or endangered under the Endangered Species Act. The U.S. Forest Service lists 28 species as being rare in the Tongass National Forest and Chugach National Forest (Muller 1981)(a), but none of these was found during the present survey.

\section{SHORELINE STABILITY}

The low bedrock shelf surrounding Back Island between low- and normal high-water lines protects the shoreline from wave-induced erosion during all but the highest tides and moderately strong winds. Some erosion of upland soils at the extreme high-tide line is evident around the island. Dense root systems of trees and undergrowth exposed at the high-tide line provide some protection to the soils from wave-induced erosion.

Intertidal fill associated with the construction of the pier on Back Island could have a minor destabilizing effect on the shoreline in the vicinity of the pier. When fill placed in the intertidal zone is subjected to wave action, wave energy is transferred laterally along the fill and causes increased erosion at the points where the fill contacts the shoreline. In the case of the alternate pier sites on Back Island, the extreme high-tide shoreline is composed of unconsolidated soils that are currently subject to wave-induced erosion during extreme high tides and moderate wave action. Placement of fill at the alternative pier sites will increase the potential for wave-induced erosion of upland soils at the flanks of the fill. This can be minimized,

(a) Muller, M. C. 1981. A Working List of Sensitive Plants for the Tongass and Chugach National Forests. Unpublished Report. U.S. Forest Service, Ketchikan, Alaska. 
however, by constructing the fill without any sharp corners or abrupt changes in curvature and by protecting the flanks of the fill with riprap.

Improper placement of the fill could also cause damage to the pier. In the intertidal zone, fill can present a barrier to the free movement of logs and driftwood along the shoreline during extreme high tides and moderately strong winds. Logs and driftwood trapped on the upwind side of the fill and pier could damage the pier during periods of moderately large breaking waves.

The root systems of trees and undergrowth along the extreme high-tide shoreline provide protection of upland soils against wave-induced erosion by dissipating the energy of breaking waves. Construction of the access road along the shoreline between the pier and the Range Operations Building may require clearing vegetation from the extreme high-water shoreline. Loss of vegetation will increase the potential for wave-induced erosion of the roadway and upland soils between the pier and Range Operations Building, requiring that the seaward edge of the roadway be protected with riprap. It would be prudent to leave a strip of vegetation between the access road and extreme high-water shoreline and in front of the Range Operations Building to lessen the need for riprap along the shoreline. 


\section{REFERENCES}

Abbott, A. A., and G. T. Hollenberg, 1976. Marine Algae of California. Stanford University Press, Stanford, California.

Barr, N., and L. Barr. 1983. Under Alaskan Seas. Alaska Northwest Publishing Company, Anchorage, Alaska.

Guberlet, M. L. 1956. Seaweeds at Ebb Tide. University of Washington Press, Seattle, Washington, and London.

Hitchcock, C. L., and A. Cronquist. 1974. Flora of the Pacific Northwest, An Illustrated Manual. University of Washington Press, Seattle, Washington, and London.

Hulten, E. 1968. Flora of Alaska and Neighboring Territories - A Manual of the Vascular Plants. Stanford University Press, Stanford, California.

Kessler, D. W. 1985. Alaska's Saltwater Fishes and Other Sea Life. Alaska Northwest Publishing Company, Anchorage, Alaska.

Kozloff, E. N. 1976. Keys to the Marine Invertebrates of Puget Sound, the San Juan Archipelago, and Adjacent Regions. University of Washington Press, Seattle, Washington, and London.

Kozloff, E. N. 1973. Seashore Life on the Northern Pacific Coast. University of Washington Press, Seattle, Washington, and London.

Johnson, M. E., and H. J. Snook, 1927. Seashore Animals of the Pacific Coast. Dover Publications, Inc., New York.

Lebednik, P. A., and J. F. Palmisano. 1977. "Ecology of Marine Algae." In The Environment of Amchitka Island, Alaska, eds. M. L. Meritt and R. G. Fuller, pp. 353-393, TID-26712. Published by the Technical Information Center for the Energy Research and Development Administration, Springfield, Virginia.

Mason, H. L. 1957. A Flora of the Marshes of California. University of California Press, Berkeley and Los Angeles, California.

Meehan, T. E., and D. E. Bramlet. 1983. Terrestrial Vegetation and Wildlife, Annual Environmental Report, Quartz Hill Molybdenum Project, Southeast Alaska. Tech. Memo., VTN Environmental Services, Irvine, California.

O'Clair, C. E. 1977. "Marine Invertebrates in Rocky Intertidal Communities." In The Environment of Amchitka Island, Alaska, eds. M. L. Meritt and R. G. Fuller, pp. 395-449, TID-26712. Published by the Technical Information Center for the Energy Research and Development Administration, Springfield, Virginia. 
Ricketts, E. F., and J. Calvin. 1939. Between Pacific Tides. Stanford University Press, Stanford, California.

Scagel, R. F. 1966. "Marine Algae of British Columbia and Northern Washington. I. Chlorophyceae (Green Algae)." Bul1. Natl. Mus., Can. 207:1-257.

Scagel, R. F. 1971. Guide to Common Seaweeds of British Columbia. Handbook 27. British Columbia Provincial Museum, Victoria, British Columbia.

Strand, J. A., J. R. Skalski, L. L. Faulkner, C. W. Rodman, D. W. Carlile, R. M. Ecker, A. D. Nicholls, J. V. Ramsdell and M. J. Scott. 1986. Southeast Alaska Acoustic Measurement Facility (SEAFAC) Environmenta T Data Base Review, Evaluation, and Upgrade. PNL-5867, Pacjfic Northwest Laboratory, Richland, Washington.

Strand, J. A., and J. S. Young. 1986. Reconnaissance of Intertidal and Subtidal Zones of Back Island, Behm Canal, Southeast Alaska. PNL-6016, Pacific Northwest Laboratory, Richland, Washington.

U.S. Department of the Interior and U.S. Department of Commerce. 1985. Report of Field Investigations - Coco Harbor, Rose Inlet and Ham Cove, Dall Is Tand, Port Caldera, Hetta Inlet near Sulzer and near Jumbo Island, Polk Inlet, Kina Cove, and Tolstoi Bay, Prince of wales IsTand. U.S. Department of the Interior, Fish and Wildlife Service, Southeast Alaska Ecological Services, Ketchikan, Alaska, and the U.S. Department of Commerce, National Oceanic and Atmospheric Administration, National Marine Fisheries Service, Environment Assessment Division, Juneau, Alaska.

VTN. 1980. 1980 Aquatic Biology Annual Environmental Baseline Report, Quartz Hill Molybdenum Project, Southeast Alaska. United States Borax and Chemical Corp., Los Angeles, California.

VTN. 1981. 1981 Aquatic Biology Annual Environmental Report, Quartz Hill Molybdenum Project, Southeast Alaska. United States Borax and Chemical Corp., Los Angeles, Californía.

VTN. 1982a. 1982 Nursery Studies - Shellfish, Boca de Quadra and Wilson Arm/Smeaton Bay, Quartz Hill Molybdenum Project, Southeast Alaska. United States Borax and Chemical Corp., Los Angeles, California.

VTN. 1982b. 1982 Distribution, Abundance and Food Habits of Juvenile Salmon at the Heads of Wilson Arm/Smeaton Bay and Boca de Quadra, Quartz Hill Molybdenum Project, Southeast Alaska. Unjted States Borax and Chemical Corp., Los Angeles, California.

VTN. 1982c. 1982 Terrestrial Vegetation and Wildlife Annual Environmental Report, Quartz Hill Molybdenum Project, Southeast Alaska. United States Borax and Chemical Corp., Los Angeles, California.

Waaland, J. R. 1977. Common Seaweeds of the Pacific Coast. Pacific Search Press/Nature, Seattle, Washington. 
APPENDICES 
TABLE A.1. Summary of Organisms Observed in Intertidal and Subtidal Zones of Back Island, June 1987

Transect Number

Taxon

Cholorophyta

Ulva/Monostroma complex

Blidingia minima

var. subsalsa

Filamentous green

Phaeophyta

Fucus distichus

Agarum sp.

Costaria costata

Alaria marginata

Rhodophyta

Corallina sp.

Constantinea simplex

Halosaccion glandiforme

Rhodomela larix

Zosteraceae

Zostera marina

Porifera

Myxilla incrustans

Coelenterata (Anthozoa)

Pachycerianthus fimbriatus

Tealia lofotensis

Ectoprocta

Heteropora sp.

Annelida (Polychaeta)

Serpula vermicularis

$10 \quad \underline{11} \quad \underline{12} \quad \underline{13} \quad \underline{14} \quad \underline{15} \quad \underline{16} \quad \underline{17} \quad \underline{18}$

$\begin{array}{lllllllll}x & x & x & x & x & x & x & x & x\end{array}$

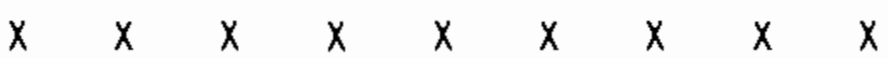

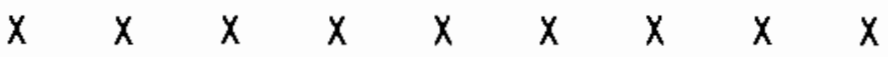

$\begin{array}{lllllllll}x & x & x & x & x & x & x & x & x\end{array}$

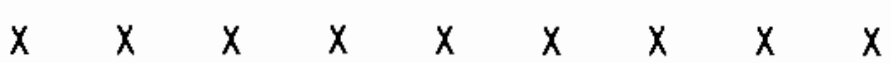

$x$

$x \quad x \quad x \quad x$

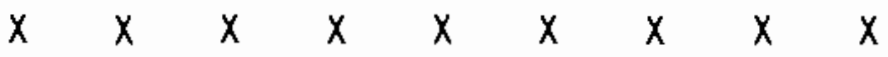

$\begin{array}{llll}x & x & x & x\end{array}$

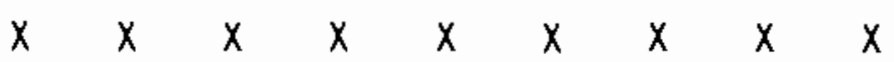

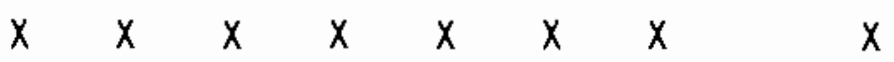

$\begin{array}{lll}x & x & x \\ x\end{array}$

$x \quad x \quad x \quad x$

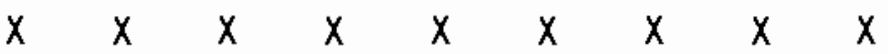


TABLE A.1. Summary of Organisms Observed in Intertidal and Subtidal Zones of Back Island, June 1987 (contd)

Taxon

Mollusca (Amphineura)

Tonicella lineata

Cryptochiton stelleri

Mollusca (Gastropoda)

Berthella californica

Melibe leonina

Notoacmea scutum

Acmaea sp.

Littorina sitkana

Searlesia dira

Calliostoma ligatum

Ceratostoma foliatum

Olivella baetica

Fusitriton oregonensis

Lunatia lewisii

Mollusca (Bivalvia)

Mytilus edulis

Chlamys hastata hericia

Pododesmus cepio

Hinnites multirugosus

Arthropoda

Balanus sp.

Pagurus spp.

Pandalus danae

Telmessus cheiragonus

Phyllolithodes papillosus

Pugettia gracilis
Transect Number

$\begin{array}{lllllllll}10 & 11 & 12 & 13 & 14 & 15 & 16 & \underline{17} & 18\end{array}$

$x$

$x$ 
TABLE A.1. Summary of Organisms Observed in Intertidal and Subtidal Zones of Back Island, June 1987 (contd)

Transect Number

Taxon

Echinodermata

Cucumaria miniata

Dermasterias imbricata

Evasterias troschelii

Parastichopus californicus

Pisaster ochraceus

Pycnopodia helianthoides

Strongylocentrotus droebachiensis

strongylocentrotus

franciscanus

Ophiura sarsij

Luidia foliolata

Chordata (Urochordata)

Cnemidocarpa finmarkiensis

Halocynthia aurantium

$\begin{array}{lllllllll}10 & 11 & 12 & 13 & 14 & 15 & 16 & 17 & 18\end{array}$

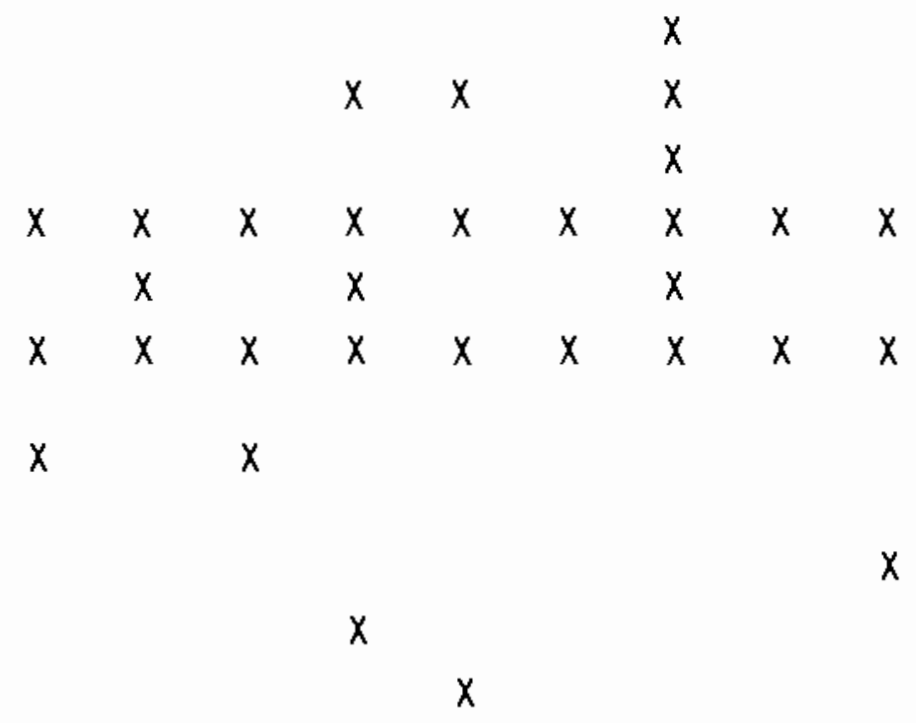

$x \quad x$

$x$ 
,

,

, 
TABLE B.1. Sumnary of Dominant Terrestrial Plants Observed in Vicinity of Transect 6 from High-Water Line to Tree Line

Family Umbelliferae Angelica lucida Common name: sea coast angelica

Family Primulaceae Dodecatheon pulchellum (Raf.) Merr. ((subsp. superbum Pennel \& Stair) Hult.))

Common name: few-flowered shooting star

Family Compositae Achillea (millifolium L.)

Common name: yarrow or milfoil

Family Plantaginaceae

Plantago maritima L. subsp. juncoides (Lam.) Hult. Common name: sea plantain Plantago canescens Adams

Family Rosaceae Potentilla pacifica How. (acc. to Hitchcock) or Potentilla egedii Wormsk. ((subsp. grandis (Torr. \& Gray Hult.)) (acc. to Hulten) Common name: Pacific silver cinquefoil

Family Ranunculus Ranunculus orthoryhnchus Hook. ((subsp. alaschensis (Benson) Hult.))

Family Juncaceae Juncus arcticus Willd. (subsp. sitchensis Engelm.) (acc. to Hulten) or Juncus balticus Willd. var. balticus (acc. to Hitchcock)

Family Cyperaceae Carex lyngbyei Hornem. Common name: sedge

Family Graminae Elymus mollis Trin. (acc. to Hitchcock) Common name: wildrye or ryegrass 


\section{DISTRIBUTION}

No. of

Copies

OFFSITE

25 David Taylor Naval Shipyard R \& D Center Bremerton, WA 98310

J. V. Dorigan

U.S. Department of Energy ER-75 GTN Washington, D.C. 20545

30 DOE Technical Information Center

Helen McCammon

Ecological Research Division EV-34

Majl Stop E-201 GTN

Washington, D.C. 20545
No. of

Copies

ONSITE

DOE Richland Operations Office

J. J. Sutey/P. K. Clark

2 Battelle/Marine Research Laboratory

J. A. Trelstad (2)

25 Pacific Northwest Laboratory

D. W. Dragnich

R. M. Ecker (10)

M. J. Graham

J. M. Hales

P. C. Hayes

S. A. Kren]

R. L. Skaggs

J. A. Stott lemyre

J. A. Strand (2)

R. E. Wildung

J. S. Young (2)

Publishing Coordination (2)

Technical Report Files 
